\title{
Food intake and nutritional status of preschool from maroon communities of the state Alagoas, Brazil
}

\author{
Consumo alimentar e estado nutricional de pré-escolares das comunidades remanescentes dos quilombos \\ do estado de Alagoas
}

Consumo alimentar y estado nutricional de pre-escolares de las comunidades remanecientes de los quilombos de la provincia de Alagoas

Fernanda Maria de B. Leite', Haroldo da Silva Ferreira', Myrtis Katille de A. Bezerra1 ${ }^{1}$, Monica Lopes de Assunção ${ }^{1}$, Bernardo Lessa Horta²

\section{ABSTRACT}

Objective: To assess the dietary intake and the nutritional status of children from Alagoas maroon communities.

Methods: Cross-sectional study involving 724 children (12-60 months) from 39 Alagoas maroon communities. The nutritional status was investigated by anthropometric, biochemical (hemoglobin) and food consumption indicators.

Results: The prevalence of anemia, stunting and obesity were, respectively, 48.0, 9.7 and 6.0\%. The children had a monotonous eating pattern and a considerable prevalence of inadequate intake of zinc $(17.0 \%)$, folate $(18.1 \%)$, iron (20.2\%) and vitamins A (29.7\%) and C (34.3\%). Compared to the other socioeconomic classes, the E class children had lower average consumption $(p<0.05)$ for energy, carbohydrate, vitamins $\mathrm{A}$ and $\mathrm{C}$, folate, iron, zinc and phosphorus.

Conclusions: Anemia is a serious Public Health problem. The prevalence of chronic malnutrition and obesity were similar to those observed for the children in the State as a whole, where a nutritional transition process is occuring. There was a high prevalence of inadequate food intake risk for zinc, folate, iron and vitamins A and C, suggesting the need for nutritional education actions.
Key-words: food consumption; nutritional status; child, preschool.

\section{RESUMO}

Objetivo: Avaliar o consumo alimentar e o estado nutricional das crianças das comunidades quilombolas de Alagoas.

Métodos: Estudo transversal envolvendo 724 crianças (12 a 60 meses) das 39 comunidades quilombolas de Alagoas. A condição nutricional foi investigada por meio de indicadores antropométricos, bioquímico (hemoglobina) e de consumo alimentar.

Resultados: As prevalências de anemia, de déficit estatural e de obesidade foram, respectivamente, 48,0, 9,7 e $6,0 \%$. As crianças tinham um padrão alimentar monótono e uma considerável prevalência de inadequação na ingestão de zinco $(17,0 \%)$, folato $(18,1 \%)$, ferro $(20,2 \%)$ e vitaminas A $(29,7 \%)$ e C $(34,3 \%)$. Quanto às demais classes, as crianças da classe $\mathrm{E}$ apresentaram menores médias de consumo $(\mathrm{p}<0,05)$ para energia, carboidrato, vitaminas A e C, folato, ferro, zinco e fósforo.

Conclusões: A anemia é um grave problema de Saúde Pública. As prevalências de desnutrição crônica e de obesidade se assemelharam às observadas para as crianças do estado como um todo, no qual ocorre o processo de transição
Instituição: Laboratório de Nutrição Básica e Aplicada da Faculdade de Nutrição da Universidade Federal de Alagoas (UFAL), Maceió, AL, Brasil

${ }^{1}$ Faculdade de Nutrição da UFAL, Maceió, AL, Brasil

${ }^{2}$ Universidade Federal de Pelotas (UFPel), Pelotas, RS, Brasil
Endereço para correspondência:

Haroldo da Silva Ferreira

Avenida Pilar, 550 - Cruz das Almas

CEP 57038-480 - Maceió/AL

E-mail: haroldo.ufal@gmail.com

Fonte financiadora: Conselho Nacional de Desenvolvimento Científico e Tecnológico (CNPq) - processo 478607/2007-5

Conflito de interesse: nada a declarar

Recebido em: 6/3/2013

Aprovado em: 19/5/2013 
nutricional. Houve alta prevalência de risco de inadequação alimentar para zinco, folato, ferro e vitaminas A e C, sendo necessárias ações de educação nutricional.

Palavras-chave: consumo de alimentos; estado nutricional; pré-escolar.

\section{RESUMEN}

Objetivo: Evaluar el consumo alimentar y el estado nutricional de los niños de las comunidades quilombolas de Alagoas.

Métodos: Estudio transversal implicando a 724 niños (12 a 60 meses) de las 39 comunidades quilombolas de Alagoas. La condición nutricional fue investigada mediante indicadores antropométricos, bioquímico (hemoglobina) y de consumo alimentar.

Resultados: Las prevalencias de anemia, de déficit estatural y de obesidad fueron, respectivamente, 48,0, 9,7 y 6,0\%. Los niños tenían un estándar alimentar monótono y una considerable prevalencia de inadecuación en la ingestión de zinc (17\%), folato $(18,1 \%)$, hierro $(20,2 \%)$ y vitaminas A $(29,7 \%)$ y C $(34,3 \%)$. Respecto a las otras clases, los niños de clase $\mathrm{E}$ presentaron menores promedios de consumo $(p<0,05)$ para energía, carbohidrato, vitaminas $\mathrm{A}$ y $\mathrm{C}$, folato, hierro, zinc y fósforo.

Conclusiones: La anemia es un grave problema de Salud Pública, situación compatible con el cuadro de inadecuaciones alimentarias observado. Las prevalencias de desnutrición crónica y obesidad se asemejan a las observadas para los niños de la provincia como un todo, en el que se viene observando proceso de transición nutricional. Hubo alta prevalencia de riesgo de inadecuación alimentar para zinc, folato, hierro y vitaminas A y $\mathrm{C}$, siendo necesarias acciones de educación nutricional.

Palabras clave: consumo de alimentos; estado nutricional; pre-escolar.

\section{Introduction}

Brazil's Maroon communities have a long history of social exclusion, food insecurity and precarious living conditions, all of which have a direct influence on the health-disease process and, consequently, on the life expectancies of their inhabitants ${ }^{(1)}$.

A census of Brazilian Maroon communities, the Chamada Quilombola ${ }^{(2)}$, showed that $90.9 \%$ of the families in these communities belong to economic classes $\mathrm{D}$ or $\mathrm{E}$, which is a considerably larger proportion than is estimated for populations in Brazil's urban areas $(34.3 \%)^{(3)}$. The census also found that $43.6 \%$ of the mothers of preschool children had spent fewer than 5 years in education ${ }^{(2)}$, which is also considerably higher than the same figure for Brazilian women aged 25 to $30(16.9 \%)^{(2)}$. In a situation such as this, the plight of children is especially worrying, considering their greater biological vulnerability, in particular their greater susceptibility to nutritional disorders caused by inadequate access to nutrition ${ }^{(4)}$.

Despite this, no studies of the adequacy of the dietary intake of Maroon children had previously been conducted in Brazil. Dietary surveys are of great value for identifying indicators that can be used to delineate and evaluate the magnitude of dietary deficiencies ${ }^{(5)}$.

In 2008 there were 39 Maroon communities in the Brazilian state of Alagoas and there was absolutely no data on their nutritional and health status. This study investigated the dietary intake and nutritional status of the preschool children in these communities.

\section{Methods}

This was a cross-sectional study of all Maroon families in Alagoas who had children aged 12 to 60 months.

There is no consensus on the number of Maroon communities in Brazil or on the size of their populations ${ }^{(2)}$ and so preschool children were selected from every household in which there were children within the target age range in all of the 39 Maroon communities in Alagoas that were known of in 2008. If there were more than one preschool child in any given household, just one was chosen at random to take part in the study.

Data collection was conducted during home visits between July and November of 2008 using a semi structured questionnaire that had undergone pre-testing in a pilot study. Either the child's mother or carer was interviewed. All interviews were conducted by eight students studying for Master's degrees in nutrition (five nutritionists, one physician, one speech therapist and one physical education professional), assisted by eight undergraduate nutrition students and under constant supervision by the project coordinator.

Data on health disorders were obtained by asking the interviewee whether the child had had any type of health problem during the previous 15 days and, in the case of an affirmative answer, what those problems were ${ }^{(6)}$. Socioeconomic status was profiled in terms of educational level and economic occupation activity of the head of the family and enrollment 
on government welfare programs and economic class defined according to a scale developed by the Brazilian Association of Market Research Companies (ABEP - Associação Brasileira de Empresas de Pesquisa) $)^{(3)}$.

Anthropometric data were collected in duplicate, by a nutritionist and a physical education professional who had been trained in advance ${ }^{(7)}$. In the event of measurement discrepancies ( $>100 \mathrm{~g}$ for weight and $>0.5 \mathrm{~cm}$ for length/height) a third measurement was taken and the measurement that most diverged from the other two discarded. The mean of two valid measurements was used for data analysis.

The length of children $\leq 2$ years old was measured using a wooden baby scale infantometer with an inextensible tape measure marked in millimeters. The height of children older than 2 years was measured using a vertical stadiometer. Children were weighed on portable electronic balances (Marte PP 180) with $180 \mathrm{~kg}$ capacity and $100 \mathrm{~g}$ sensitivity.

The weight, height, age and sex data were input to the Anthro software package, which was used to generate anthropometric indices (http://www.who.int/childgrowth/software/en/). These indices were then used as the basis for the following nutritional indicators: underweight (weight-for-age $<-2 z$ ), wasting (weight-for-height $<-2 z$ ), stunting (height-for-age $<-2 z$ ) and obesity (weight-for-height $>2 z$ ). The outlier elimination function was activated throughout data analysis to remove biologically implausible results using the following cutoff points: $z<-6$ or $>5$ for weight-for-age, $\mathrm{z}<-5$ or $>5$ for weight-for-height and $\mathrm{z}<-6$ or $>6$ for height-for-age (http://www.who.int/childgrowth/software/ WHOAnthro2005_PC_Manual.pdf).

Hemoglobin $(\mathrm{Hb})$ levels were assayed using a portable hemoglobin meter $\left(\mathrm{HemoCue}^{\circledR}\right.$ ) to test a drop of blood acquired by finger stick. Children were defined as anemic if their $\mathrm{Hb}$ level was below $11 \mathrm{~g} / \mathrm{dL}^{(8)}$.

A 24-hour recall dietary survey was administered to interviewees in order to collect data on the number of meals, types of foods and methods of preparation and the quantities eaten by the children during the previous 24 hours. A second 24-hour recall was also administered to a $27 \%$ subsample, in order to provide a basis to control for intraindividual variability of $\operatorname{diet}^{(9)}$.

Nutrient intakes were calculated using $N u t W i n^{\circledR}$ version 1.5 (http://www.unifesp.br/dis/produtos/nutwin/index.htm). Prevalence rates of deficient intakes of macro and micronutrients were calculated using the Dietary Reference Intakes (DRIs) published by the Institute of Medicine $(\mathrm{IOM})^{(10)}$. taking the Estimated Average Requirement (EAR) as cutoff points ${ }^{(11)}$.

Individual energy requirements and the degree of adequacy of protein and carbohydrate intakes and micronutrient intakes were estimated using Estimated Energy Requirements (EER) and EARs, respectively. Where no EAR has been established, which is the case of calcium for example, the Adequate Intake (AI) figures were used. The distribution of energy provision across macronutrients was analyzed against the Acceptable Macronutrient Distribution Range (AMDR) ${ }^{(10)}$.

The adequacy of habitual energy intake was estimated using Body Mass Index for age (BMIa). The children's results were classified as recommended by the World Health Organization $(\mathrm{WHO})^{(7)}$. using cutoff points of $\mathrm{z}<-2$ and $\mathrm{z}>2$ for cases of Deficit or Excess respectively. This approach is based on the assumption that undernourishment and obesity are the result of negative and positive net energy respectively. The adequacy of current energy intake was estimated as the ratio between energy intake according to the 24-hour recall and the EER. Variations of plus or minus $10 \%$ with respect to the EER were considered within the normal range. Ratios below 0.9 were assumed to be indicative of low energy intake and ratios above 1.1 of indicate excessive energy intake ${ }^{(12)}$. The micronutrients analyzed were chosen on the basis of their relationships with child growth and development (vitamins $\mathrm{A}$ and $\mathrm{C}$ and the minerals calcium, phosphorous and zinc) and with anemia (folate, vitamin $\mathrm{C}$ and iron).

The children were divided into two age groups for analysis of dietary intake, following the two recommendation ages: from 1 to 3 years and from 4 to 5 years, which are the lifecycle stages used for DRIs ${ }^{(10)}$.

Children whose mothers or carers were unaware of what they were fed the previous day were excluded $(n=6 ; 0.7 \%)$, as were those who reported atypical intake on the previous day because of illness or festivities $(n=4 ; 0.5 \%)$.

Statistical analysis was as follows: normality and homogeneity of variances were verified using the KolmogorovSmirnov and Levene tests respectively; means were compared using Student's $t$ test, analysis of variance (ANOVA), the Mann-Whitney test or the Kruskal-Wallis test, according to the characteristics of the variables involved; the Tukey test was used post hoc after comparison of more than two means; and the significance level was set at $5 \%$.

The study was approved by the Research Ethics Committee at the Universidade Federal de Alagoas (hearing number 004691/2009-16).

\section{Results}

A total of 781 children aged 12 to 60 months were identified, but losses, refusals and absent carers $(n=47 ; 6.0 \%)$ 
plus exclusions ( $\mathrm{n}=10 ; 1.2 \%)$ reduced the sample analyzed to 724 children.

The mean age of the children studied was 2.6 years and 358 (49.4\%) of them were male. The most prevalent health problems were infections of the respiratory system (57.3\%) and diarrhea (26.1\%).

The majority of families were classified as economic class economic D (35.5\%) or E (57.5\%). The most common occupation of the heads of families was agriculture $(60.9 \%)$. The majority of families (76.4\%) were beneficiaries of government welfare programs, with $98.7 \%$ registered on the low-income family support program, the Programa Bolsa Familiar (PBF).

Six hundred and sixty-three (663) of the children who had their dietary intake assessed also had $\mathrm{Hb}$ assayed. Mean concentration was $11.0 \pm 1.6 \mathrm{~g} / \mathrm{dL}$ and the prevalence of anemia was $48 \%$.

Twenty-eight (28) of the 724 children eligible for the study were either too active or too aggressive during data collection for anthropometric measurements to be taken, leaving 696 children who were assessed. Twentysix of these were excluded from analysis because their measurements were biologically implausible (outliers). As a result, 670 preschool children were included in the anthropometric assessment (Table 1). The most common nutritional disorders were stunting $(9.7 \%)$, indicative of chronic malnutrition, and obesity $(6 \%)$.

The dietary profiles showed that the mean number of meals per day was 4.3. Analysis of the food groups involved revealed a diet with little variety and high intakes of cereals $(39.3 \%)$, meat $(13.7 \%)$ and milk and dairy products $(12.7 \%)$. There were low intakes of fruit $(5.4 \%)$, vegetables $(0.8 \%)$ and greens $(0.5 \%)$. Mean energy intake was $933.47 \pm 204.91 \mathrm{kcal} /$ day, while mean estimated energy requirement was $1,275.76 \pm 176.35 \mathrm{kcal} /$ day.

It was found that $70.1 \%$ of the children had energy intake $<10 \%$ of EER on the day prior to interview, while $13.6 \%$ had intakes $10 \%$ above the reference. However, when energy consumption was analyzed on the basis of BMIa, it was found that just $1.3 \%$ of the children had status compatible with negative net energy, while $6.9 \%$ had intakes above their requirements.

Analysis of the number of calories provided by macronutrients showed that just $7.1 \%$ of children aged 1 to 4 years and $5 \%$ of those aged 4 to 5 years had carbohydrate intake below the minimum recommended level and none of the children were below the limit for protein. However, there was a high proportion of children with intake of lipids below the recommended level: $60.3 \%$ of those 1 to 3 years old and $48.9 \%$ of 4 to 5 -year-olds.

There was a considerable risk of deficient intake of zinc, vitamins A and C, folate and iron (Table 2). However, there was no statistically significant difference $(p=0.31)$ between mean iron intakes of anemic children and non-anemic children.

When nutrient intakes were broken down by economic class, children from class $\mathrm{E}$ had lower mean intakes than those from higher economic strata for the majority of dietary variables, specifically: energy $(p=0.01)$, carbohydrates $(p=0.01)$, vitamin $\mathrm{A}(p<0.01)$, vitamin $\mathrm{C}(p<0.01)$, folate $(p<0.01)$, iron $(p<0.01)$, zinc $(p<0.01)$ and phosphorous $(p=0.03)$ (Table 3).

\section{Discussion}

The families studied here are living in highly precarious socioeconomic conditions, given that more than $90 \%$ were classified into economic classes D or E, which is similar to results reported by the Chamada Quilombola survey of Maroon communities $(90.9 \%)^{(2)}$. The majority of these families were beneficiaries of the Federal Government's PBF welfare program, which was designed to guarantee access to adequate nutrition for people living in poverty ${ }^{(13)}$.

In view of the similarity between the results observed in this study and the published data on prevalence of stunting and obesity in the state of Alagoas, which show a fall in the

Table 1 - Nutritional status of children from remnant Maroon communities, according to several different anthropometric indices $(n=670)$. Alagoas, Brazil, 2008

\begin{tabular}{lccc}
\hline Indices & Classification* & $\mathbf{n}$ & Prevalence (\%) \\
\hline \multirow{2}{*}{ Weight-for-age } & Deficit & 19 & 2.8 \\
\hdashline Height-for-age & Excess & 20 & 3.0 \\
\hdashline & Deficit (stunting/chronic malnutrition) & 65 & 9.7 \\
\hdashline & Excess & 7 & 1.0 \\
\hdashline Weight-for-height & Deficit (wasting/acute malnutrition) & 9 & 1.3 \\
& Excess (overweight/obesity) & 40 & 6.0 \\
\hline
\end{tabular}

Deficit: $z<-2$; Excess: $z>2$ 
prevalence of stunting and an increase in the number of obese children ${ }^{(14)}$, it can be speculated that the same tendency has been affecting Maroon children. In this case, although the findings show that the PBF has been correctly focused on its target public, in addition to wealth redistribution it is also necessary to implement nutritional education interventions to ensure that the families receiving this benefit are able to choose foods that will in fact improve their health.

Castiñeira $e t$ al ${ }^{(15)}$ conducted a review of the effects of the PBF and found that although the majority of families receiving benefits enjoyed an increase in the variety of foods eaten, there was an increase in consumption of foods with high-calorie density and low nutritional value, in detriment to intake of fruit and vegetables, which was also observed in this study.

The anthropometric profile of the children studied showed that prevalence of weight-for-height deficit was negligible. A similar situation was reported by the Chamada Quilombola survey ${ }^{(2)}$ and the 2006 National Demographic and Health Census (PNDS-2006 - Pesquisa Nacional de Demografia e Saúde ${ }^{(16)}$. Although height-for-age deficit was the most prevalent anthropometric disorder in the population investigated, the figure observed $(9.7 \%)$ was lower than reported by the Chamada Quilombola survey $(15.0 \%)^{(2)}$. Notwithstanding, it was still higher than the $7 \%$ reported by the PNDS-2006 $6^{(16)}$ or the $6 \%$ reported by the Family Budgets Survey (POF-2008/2009 - Pesquisa de Orçamentos Familiares) ${ }^{(17)}$.

Height-for-age deficits in children indicate delayed linear growth and, on the level of populations, make it possible to estimate chronic lack of access to adequate nutrition ${ }^{(17)}$.

Although the prevalence of obesity observed in this study was lower than the rate of chronic malnutrition, it suggests that the Maroon children are going through a process of nutritional transition, in common with the Brazilian population as a whole ${ }^{(18)}$. This cannot be confirmed because of the lack of previous studies that would make it possible to analyze the tendencies of these disorders over time.

Table 2 - Habitual intakes of energy, macronutrients and micronutrients in children from remnant Maroon communities, by age group. Alagoas, Brazil, 2008

\begin{tabular}{|c|c|c|c|c|c|}
\hline Energy and nutrients & Age group & $\mathbf{n}$ & EAR & Mean \pm SD & Deficiencies (\%)* \\
\hline \multirow{2}{*}{ Energy (kcal) } & 1 - 4 years & 513 & - & $953.0 \pm 254.3$ & - \\
\hline & $4-5$ years & 173 & - & $914.0 \pm 155.5$ & - \\
\hline \multirow{2}{*}{ Carbohydrates (g) } & 1 - 4 years & 534 & 100 & $131.3 \pm 43.7$ & 23.9 \\
\hline & $4-5$ years & 178 & 100 & $136.3 \pm 47.9$ & 22.6 \\
\hline \multirow{2}{*}{ Protein $(\mathrm{g} / \mathrm{kg})$} & 1 - 4 years & 507 & 0.87 & $3.1 \pm 0.9$ & $<1.2$ \\
\hline & $4-5$ years & 173 & 0.76 & $2.4 \pm 0.5$ & $<1.2$ \\
\hline \multirow{2}{*}{ Lipids (g) } & 1 - 4 years & 534 & - & $30.1 \pm 11.0$ & $* *$ \\
\hline & $4-5$ years & 178 & - & $25.6 \pm 2.9$ & $* *$ \\
\hline \multirow{2}{*}{ Vitamin $A^{* * *}$ ( $\left.\mu g R A E\right)$} & 1 - 4 years & 546 & 210 & $362.0 \pm 317.6$ & 31.9 \\
\hline & $4-5$ years & 178 & 275 & $180.8 \pm 125.6$ & 23.0 \\
\hline \multirow{2}{*}{ Iron (mg) } & 1 - 4 years & 546 & 3 & $6.7 \pm 4.3$ & 20.0 \\
\hline & $4-5$ years & 178 & 4.1 & $6.3 \pm 2.7$ & 20.6 \\
\hline \multirow{2}{*}{ Zinc (mg) } & 1 - 4 years & 546 & 2.5 & $5.2 \pm 2.3$ & 11.7 \\
\hline & $4-5$ years & 178 & 4 & $4.5 \pm 1.8$ & 33.4 \\
\hline \multirow{2}{*}{ Calcium (mg) } & 1 - 4 years & 546 & $500^{* * * *}$ & $560.4 \pm 348.9$ & $* * * * *$ \\
\hline & $4-5$ years & 178 & $800^{* * * * *}$ & $410.6 \pm 267.8$ & $* * * * * *$ \\
\hline \multirow{2}{*}{ Folate $(\mu \mathrm{g})$} & 1 - 4 years & 546 & 120 & $82.3 \pm 52.2$ & 23.6 \\
\hline & $4-5$ years & 178 & 160 & $74.8 \pm 26.9$ & $<1.2$ \\
\hline \multirow{2}{*}{ Phosphorous (mg) } & 1 - 4 years & 546 & 380 & $676.8 \pm 271.2$ & 13.8 \\
\hline & $4-5$ years & 178 & 405 & $582.8 \pm 157.4$ & 13.1 \\
\hline \multirow{2}{*}{ Vitamin C (mg) } & 1 - 4 years & 546 & 13 & $33.0 \pm 42.4$ & 31.9 \\
\hline & $4-5$ years & 178 & 22 & $43.94 \pm 98.43$ & 41.3 \\
\hline
\end{tabular}

${ }^{*}$ Risk of inadequate nutrient intake; ** no recommendation has been defined; ***in retinol activity equivalents (RAE). 1 RAE: $1 \mu \mathrm{g}$ of retinol, $12 \mu \mathrm{g}$ of $\beta$-carotene, $24 \mu \mathrm{g}$ of $\alpha$-carotene or $24 \mu \mathrm{g}$ of $\beta$-cryptoxanthin; ${ }^{* * * *}$ adequate intake (Al) for calcium. It is believed that at this stage of development, the Al supplies the requirements for all individuals in the group, but lack or uncertainty of information prevents specification of a correct percentage; ${ }^{* * * * *}$ possibility that intake is adequate (mean intake over the Al); ${ }^{* * * * * *}$ cannot be classified because below the Al

EAR: Estimated Average Requirement; SD: standard deviation 
Notwithstanding, the $6 \%$ prevalence of obesity that was detected is more similar to than different from prevalence rates for children in other settings in which nutritional transition has been identified: $9.7 \%$ in the state of Alagoas ${ }^{(14)} ; 5.4 \%$ in a sample of the national Brazilian Maroon population ${ }^{(2)}$ and $6.6 \%$ among Brazilian children in general ${ }^{(16)}$.

Studies undertaken in specific communities with low socioeconomic status have reported similar results or even worse results than those described here, suggesting that the anthropometric profile of Maroon children in Alagoas is more influenced by factors associated with low income than by the fact that they are from Maroon communities. A study ${ }^{(19)}$ of 2,075 children from favelas in the state capital of Alagoas (Maceió) found an $8.6 \%$ prevalence of stunting and an obesity prevalence of $11.3 \%$. A study of 735 children enrolled at public day care centers in Bezerros, in provincial Pernambuco state, found prevalence rates of $6.8 \%$ for stunting and $6.1 \%$ for obesity ${ }^{(20)}$. A very worrying situation was revealed by a survey of indigenous Suruí children ${ }^{(21)}$, who had a $31.4 \%$ prevalence of stunting was and a $3.9 \%$ obesity prevalence.

Table 3 - Habitual intake of energy, macronutrients and micronutrients in children from remnant Maroon communities, by economic class. Alagoas, Brazil, 2008

\begin{tabular}{|c|c|c|c|}
\hline Energy and nutrients & Economic class* & $\mathbf{n}$ & Mean \pm SD (median) \\
\hline \multirow{3}{*}{ Energy (kcal) } & $E$ & 409 & $926.3 \pm 249.7^{\mathrm{a}}(894.9)$ \\
\hline & D & 250 & $973.8 \pm 243.2^{b}(954.4)$ \\
\hline & $\mathrm{B} 2, \mathrm{C} 1$ and $\mathrm{C} 2$ & 48 & $1044.7 \pm 249.9^{b}(1004.1)$ \\
\hline \multirow{3}{*}{ Carbohydrates (g) } & $E$ & 409 & $128.9 \pm 45.6^{a}(121.8)$ \\
\hline & D & 250 & $135.8 \pm 42.7^{\mathrm{a}, \mathrm{b}}(129.6)$ \\
\hline & $\mathrm{B} 2, \mathrm{C} 1$ and $\mathrm{C} 2$ & 48 & $148.8 \pm 46.0^{\mathrm{b}}(145.4)$ \\
\hline \multirow{3}{*}{ Protein (g/kg) } & $E$ & 387 & $2.8 \pm 0.8^{\mathrm{a}}(2.8)$ \\
\hline & D & 242 & $2.9 \pm 0.9^{a}(2.8)$ \\
\hline & $\mathrm{B} 2, \mathrm{C} 1$ and $\mathrm{C} 2$ & 45 & $2.8 \pm 0.9^{a}(2.7)$ \\
\hline \multirow{3}{*}{ Lipids (g) } & $E$ & 409 & $28.8 \pm 10.1^{\mathrm{a}}(27.1)$ \\
\hline & $\mathrm{D}$ & 250 & $30.4 \pm 9.7^{\mathrm{a}}(29.0)$ \\
\hline & $\mathrm{B} 2, \mathrm{C} 1$ and $\mathrm{C} 2$ & 48 & $31.9 \pm 7.4^{\mathrm{a}}(32.1)$ \\
\hline \multirow{3}{*}{ Vitamin $A^{* *}$ ( $\left.\mu g R A E\right)$} & $E$ & 416 & $284.3 \pm 270.0^{\mathrm{a}}(208.3)$ \\
\hline & D & 257 & $343.2 \pm 296.0^{\mathrm{b}}(268.2)$ \\
\hline & $\mathrm{B} 2, \mathrm{C} 1$ and $\mathrm{C} 2$ & 51 & $454.2 \pm 398.5^{\circ}(432.1)$ \\
\hline \multirow{3}{*}{ Iron (mg) } & $E$ & 416 & $6.1 \pm 3.6^{\mathrm{a}}(5.2)$ \\
\hline & $\mathrm{D}$ & 257 & $7.1 \pm 4.3^{\mathrm{b}}(6.1)$ \\
\hline & $\mathrm{B} 2, \mathrm{C} 1$ and $\mathrm{C} 2$ & 51 & $8.4 \pm 4.0^{c}(6.1)$ \\
\hline \multirow{3}{*}{ Zinc (mg) } & $E$ & 416 & $4.8 \pm 1.8^{\mathrm{a}}(4.5)$ \\
\hline & $\mathrm{D}$ & 257 & $5.3 \pm 2.2^{\mathrm{b}}(4.8)$ \\
\hline & $\mathrm{B} 2, \mathrm{C} 1$ and $\mathrm{C} 2$ & 51 & $5.9 \pm 2.9^{b}(5.0)$ \\
\hline \multirow{3}{*}{ Calcium (mg) } & $\mathrm{E}$ & 416 & $507.5 \pm 342.4^{\mathrm{a}}(415.4)$ \\
\hline & $\mathrm{D}$ & 257 & $537.4 \pm 327.2^{\mathrm{a}}(480.9)$ \\
\hline & $\mathrm{B} 2, \mathrm{C} 1$ and $\mathrm{C} 2$ & 51 & $584.4 \pm 335.5^{a}(515.8)$ \\
\hline \multirow{3}{*}{ Folate $(\mu \mathrm{g})$} & $E$ & 416 & $74.7 \pm 40.1^{a}(67.6)$ \\
\hline & D & 257 & $87.1 \pm 56.0^{\mathrm{b}}(70.9)$ \\
\hline & $\mathrm{B} 2, \mathrm{C} 1$ and $\mathrm{C} 2$ & 51 & $93.5 \pm 47.9^{\mathrm{b}}(86.0)$ \\
\hline \multirow{3}{*}{ Phosphorous (mg) } & $\mathrm{E}$ & 416 & $634.9 \pm 242.9^{\mathrm{a}}(598.8)$ \\
\hline & $\bar{D}$ & 257 & $669.6 \pm 252.6^{\mathrm{a}, \mathrm{b}}(622.5)$ \\
\hline & $\mathrm{B} 2, \mathrm{C} 1$ and $\mathrm{C} 2$ & 51 & $726.0 \pm 294.1^{\mathrm{b}}(697.5)$ \\
\hline \multirow{3}{*}{ Vitamin C (mg) } & $\mathrm{E}$ & 416 & $27.9 \pm 46.8^{\mathrm{a}}(16.3)$ \\
\hline & $\mathrm{D}$ & 257 & $44.7 \pm 79.2^{\mathrm{b}}(24.5)$ \\
\hline & $\mathrm{B} 2, \mathrm{C} 1$ and $\mathrm{C} 2$ & 51 & $42.1 \pm 44.8^{c}(31.6)$ \\
\hline
\end{tabular}

*Economic class according to the classification developed by the Brazilian Association of Market Research Companies (ABEP - Associação Brasileira de Empresas de Pesquisa, 2008); **in retinol activity equivalents (RAE). 1 RAE: $1 \mu \mathrm{g}$ of retinol, $12 \mu \mathrm{g}$ of $\beta$-carotene, $24 \mu \mathrm{g}$ of $\alpha$-carotene or $24 \mu \mathrm{g}$ of $\beta$-cryptoxanthin; a,b,c different letters indicate statistically significant differences. The same letters indicate no statistically significant difference 
The children investigated here had a diet with little variety in terms of different foods and which was basically made up of milk, cereals and meat with little consumption of fruit, vegetables or greens. A similar result was observed by Farias Júnior and Osório ${ }^{(4)}$ when they studied preschool children in the state of Pernambuco.

Energy intake was assessed by two different methods and their results were divergent. The method based on BMIa defined just $1.3 \%$ of children as having energy intake below their energy requirements, while $6.9 \%$ were eating too much. On the other hand, when the ratio between energy intake and EER was used, the figures were 70.1 and $13.6 \%$, for too little and too much energy respectively. The difference in rate of excessive energy intake is not of a large magnitude and can be attributed to chance, in view of the intraindividual variability in dietary intake from day to day. However, the discrepancy between the results for the two methods of measuring deficient energy intake merits further consideration.

Energy requirements are estimated on the basis of data from healthy individuals ${ }^{(10)}$. In the case of the population studied here, in addition to the significant percentage of individuals who had chronic malnutrition $(9.7 \%)$, the entire population's height distribution is left-shifted: while the median $\mathrm{Z}$ score for the standard curve is zero, the study population had a median of -0.66 . This is therefore a population that has suffered chronic malnutrition. In such circumstances, people's energy metabolism is reprogrammed to adjust to their habitual energy intake, and their bodies become metabolically economic ${ }^{(22)}$.

In view of this, it can be seen that the BMIa method is not robust for assessment of energy intake in populations subjected to long term dietary privation and so studies are needed that develop more appropriate resources for use with populations with these characteristics.

There was a high proportion of children with lipid intakes below the recommended level, which could prejudice their supply of essential fatty acids, indispensable for healthy physical and mental development during the first years of life ${ }^{(10)}$. Furthermore, low intake of lipids can result in negative net energy. In such a situation, proteins which should be used for plastic and/or functional uses are diverted away from these roles and oxidized to produce energy, compromising children's growth ${ }^{(23)}$.

The micronutrient profile revealed a significant risk of zinc, iron, folate, vitamin $\mathrm{A}$ and vitamin $\mathrm{C}$ deficiencies. Deficiencies in these nutrients prejudice the body's growth and development and reduce its resistance to infections ${ }^{(10)}$. In addition to the generalized linear growth deficit observed in the study population, this finding is also compatible with the elevated prevalence of respiratory infections observed in the children studied.

Insufficient iron intake was observed in around $20 \%$ of the children. However, the prevalence of anemia reached a higher level, affecting almost half of the children, which means it is a serious public health problem. When anemia prevalence rates are higher than $40 \%$, dietary factors are the primary determinants; in other words, the majority of cases are caused by insufficient consumption of iron or excessive intake of factors that inhibit uptake ${ }^{(24)}$. However, the high prevalence of anemia observed cannot be explained by inadequate intake alone, since there was no significant difference in iron intake between anemic children and non-anemic children. Interaction with other dietary deficiencies ${ }^{(25)}$, and the poor sanitary conditions of the living environment can partly explain this observation.

Despite the Maroon communities' greater social vulnerability, the prevalence of anemia was not greatly different to what has been reported for children from the state of Alagoas in general $(45 \%)^{(26)}$. However, it is higher than the figure of $20.9 \%$ for all Brazilian children in the PNDS-2006 data ${ }^{(16)}$.

Children aged 4 to 5 had low prevalence of inadequate folate intake, in contrast with the subset aged 1 to 3 years, $23.6 \%$ of whom were at risk of deficiency. It is probable that this fact is linked with the different dietary profiles of the two subsets: the older children were fed more meat, which is a good source of folate ${ }^{(27)}$, whereas the younger children ate more milk and milk-based preparation, which are poor in this vitamin ${ }^{(27)}$.

The results of this study show that the dietary intake of a considerable proportion of the children studied was inadequate in terms of several micronutrients, which may be related to organic deficiencies of these nutrients. This type of deficiency has been named "hidden hunger" and has been investigated recently, with findings showing that it is generally subclinical and occurs in the presence of a diet that provides sufficient energy, but is lacking in micronutrients. As nutritional transition continues, hidden hunger has been gaining attention as a public health problem, to the point at which it is more important than protein-energy malnutrition ${ }^{(28,29)}$.

Studies investigating the dietary intake of populations subjected to increased social vulnerability provide the justification for health managers and health professionals to promote actions that improve food selection and as a result improve the nutritional and health status of populations, thereby reducing morbidity and mortality and increasing the quality of life of individual people $e^{(30)}$. 
Notwithstanding the limitations imposed by dietary recall survey methods, the results of the study have revealed important risks of inadequate dietary intakes that are very probably compromising the health of the children studied.

It can be concluded that the majority of these children came from families with low economic status, which is a condition that is related with an increased risk of dietary intakes below the recommended levels for energy, carbohydrates, vitamin $\mathrm{A}$, vitamin $\mathrm{C}$, folic acid, iron, zinc and phosphorous. Despite this, the prevalence rates of stunting

\section{References}

1. Guerrero AF, Silva DO, Toledo LM, Guerrero JC, Teixeira P. Infant mortality rates in quilombo areas of the Municipality of Santarém - Pará, Brazil. Saude Soc 2007;16:103-10.

2. Santos LM, Paes-Souza R, Pereira LL, Henrique FC, Soares MD, Barbosa DB et al. Aspectos metodológicos da Chamada Nutricional Quilombola. Cadernos de estudos: desenvolvimento social em debate [serial on the Internet] 2008;9:15-26 [cited 2013 Apr 22]. Available from: http://www.mds. gov.br/biblioteca/secretaria-de-avaliacao-e-gestao-de-informacao-sagi/ cadernos-de-estudos/politicas-sociais-e-chamada-nutricional-quilombolaestudos-sobre-condicoes-de-vida-nas-comunidades-e-situacao-nutricionaldas-criancas-nb0-09

3. Associação Brasileira de Empresas de Pesquisa [homepage on the Internet]. Critério de Classificação Econômica Brasil - 2012 [cited 2013 Apr 22]. Available from: http://www.abep.org/novo/FileGenerate.ashx?id=297

4. Farias Júnior G, Osório MM. Alimentary profile of under-five year old children. Rev Nutr 2005;18:793-802.

5. Castro TG, Novaes JF, Silva MR, Costa NM, Franceschini SC, Tinôco AL et al. Characteristics of dietary intake, socioeconomic environment and nutritional status of preschoolers at public kindergartens. Rev Nutr 2005;18:321-30.

6. Cesar CL, Figueiredo GM, Westphal MF, Cardoso MR, Costa MZ, Gattás VL. Referred morbidity and the utilization of health services in urban areas of south-eastern Brazil: methodology. Rev Saude Publica 1996;30:153-60.

7. World Health Organization. Physical status: the use and interpretation of anthropometry. Report of a WHO Expert Committee. Technical Report Series No. 854. Geneva: WHO; 1995.

8. United Nations Children's Fund - United Nations University - World Health Organization. Iron deficiency anaemia: assessment, prevention, and control - a guide for programme managers. Geneva: WHO; 2001.

9. Willett W. Nutritional epidemiology. $2^{\text {nd }}$ ed. New York: Oxford University Press; 1998.

10. Institute of Medicine. Dietary reference intakes: the essential guide to nutrient requirements. Washington: The National Academies Press; 2006.

11. Slater B, Marchioni DL, Fisberg RM. Estimating prevalence of inadequate nutrient intake. Rev Saude Publica 2004;38:599-605.

12. Pasco JA, Nicholson GC, Brennan SL, Kotowicz MA. Prevalence of obesity and the relationship between the body mass index and body fat: cross-sectional, population-based data. PLoS ONE 2012;7:e29580.

13. Brasil - Ministério da Saúde - PNAN [homepage on the Internet]. Bolsa Família [cited 2010 Apr 8]. Available from: http://nutricao.saude.gov.br/ acao_bolsafamilia.php

14. Ferreira HS, Luciano SC. Prevalence of extreme anthropometric measurements in children from Alagoas, Northeastern Brazil. Rev Saude Publica 2010;44:377-80.

15. Castiñeira BR, Nunes LC, Rungo P. The impact of conditional cash transfers on health status: the Brazilian Bolsa Familia Programme. Rev Esp Salud Publica 2009;83:85-97. and obesity were not greatly different to what is observed for children from the state of Alagoas as a whole, indicating that the study population is also going through a process of nutritional transition. The prevalence of anemia is a severe public health problem and cannot be explained by inadequate iron intake alone, since there was no difference between anemic children and non-anemic anemic children in terms of intake of this mineral. A high proportion of these children had intakes of energy in the form of lipids below the minimum recommended level, which could prejudice their supply of essential fatty acids.

16. Brasil - Ministério da Saúde. PNDS 2006: dimensões do processo reprodutivo e da saúde da criança. Brasília: Ministério da Saúde; 2009.

17. Brasil - Ministério do Planejamento, Orçamento e Gestão - Instituto Brasileiro de Geograifa e Estatística. Pesquisa de Orçamentos Familiares 2008-2009: antropometria e estado nutricional de crianças, adolescentes e adultos no Brasil. Rio de Janeiro: IBGE; 2010.

18. Barros AJ, Victora CG, Santos IS, Matijasevich A, Araújo CL, Barros FC. Infant malnutrition and obesity in three population-based birth cohort studies in Southern Brazil: trends and differences. Cad Saude Publica 2008;24 (Suppl 3): S417-26.

19. Silveira KB, Alves JF, Ferreira HS, Sawaya AL, Florêncio TT. Association between malnutrition in children living in favelas, maternal nutritional status, and environmental factors. J Pediatr (Rio J) 2010;86:215-20.

20. Pinho CP, Silva JE, Silva AC, Araújo NN, Fernandes CE, Pinto FC. Avaliação antropométrica de crianças em creches do município de Bezerros, PE. Rev Paul Pediatr 2010;28:315-21.

21. Orellana JD, Coimbra Jr CE, Lourenço AE, Santos RV. Nutritional status and anemia in Suruí Indian children, Brazilian Amazon. J Pediatr (Rio J) 2006;82:383-8.

22. Hoffman DJ, Sawaya AL, Verreschi I, Tucker KL, Roberts SB. Why are nutritionally stunted children at increased risk of obesity? Studies of metabolic rate and fat oxidation in shantytown children from São Paulo, Brazil. Am J Clin Nutr 2000;72:702-7.

23. Amaral ME, Morelli V, Pantoni RV, Rossetti-Ferreira MC. Feeding infants and toddlers in crèches: mediators. Interactions and programs in early child education. Rev Bras Cresc Des Hum S Paulo 1996;6:19-33.

24. Autoria não referida. Nutritional anaemias. Report of a WHO scientific group. World Health Organ Tech Rep Ser 1968;405:5-37.

25. Villalpando S, Pérez-Expósito AB, Shamah-Levy T, Rivera JA. Distribution of anemia associated with micronutrient deficiencies other than iron in a probabilistic sample of Mexican children. Ann Nutr Metab 2006;50:506-11.

26. Vieira RC, Ferreira HS, Costa AC, Moura FA, Florêncio TM, Torres ZM. The prevalence of and risk factors for anemia in preschool children in the state of Alagoas, in Brazil. Rev Bras Saude Mater Infant 2010;10:107-16.

27. Krishnaswamy K, Madhavan Nair K. Importance of folate in human nutrition. Br J Nutr 2001;85 (Suppl 2):S115-24.

28. Silva JV, Timóteo AK, Santos CD, Fontes G, Rocha EM. Food consumption of children and adolescents living in an area of invasion in Maceio, Alagoas, Brazil. Rev Bras Epidemiol 2010;13:83-93.

29. Ferraz IS, Daneluzzi JC, Vannucchi H, Jordão Jr AA, Ricco RG, Del Ciampo LA et al. Zinc serum levels and their association with vitamin A deficiency in preschool children. J Pediatr (Rio J) 2007;83:512-7.

30. Marchioni DM, Slater B, Fisberg RM. Application of dietary reference intakes for assessment of individuals. Rev Nutr 2004;17:207-16. 